\title{
PRELIMINARY RESULTS IN SURGERY OF PARKINSON'S DISEASE
}

\author{
JOSÉ AUGUSTO NASSER*, CARLOS IVAM CONFORT**, \\ ANDREI FERRAZ**, ARMANDO ALAMINOS BOUZA***
}

\begin{abstract}
The authors present the preliminary results of 20 patients selected to be operated on between January 1996 and April 1997. These patients presented one of the present indications for stereotactic posteroventral pallidotomy (PVP), such as: rigidity, akinesia/bradykinesia, gait dysfunction, drug induced dyskinesias and tremor. Every patient of this protocol was evaluated by: UPDRS score, Schwab and England scale, Hoehn and Yahr Staging Scale before and after surgery. The results in 3 months showed a remarkable improvement after PVP $(\mathrm{P}<0.01)$ in all functional assessments, except for facial expression, speech and posture. The morbidity was $5 \% .5$ patients $(25 \%)$ who were in Hoehn and Yahr 5 underwent a bilateral simultaneous PVP. In 5 patients (25\%), who had tremor, during the PVP, VIM thalamotomy was added. These preliminary results suggest that PVP is highly effective for PD symptoms.
\end{abstract}

KEY WORDS: Parkinson's disease, postero-ventral pallidotomy, VIM thalamotomy, simultaneous bilateral postero-ventral pallidotomy, stereotaxis.

\section{Resultados preliminares em cirurgia na doença de Parkinson}

RESUMO - Os autores apresentam seus resultados iniciais, no período de janeiro de 1996 até abril de 1997, em pacientes selecionados para cirurgia. Todos apresentavam indicação para palidotomia póstero ventral (PPV), como: rigidez, acinesia/bradicinesia, distúrbio da marcha, discinesia induzida por medicamentos e tremor. Todos os pacientes do protocolo foram submetidos a: UPDRS, escala de Hoehn e Yahr, escala de Schwab e England antes e após a cirurgia. Os resultados mostraram melhora significativa nos 3 meses iniciais $(\mathrm{p}<0,01)$ para todas as provas motoras exceto para expressão facial, postura e fala. A morbidade foi de $5 \% .5$ pacientes em Hoehn e Yahr 5 foram submetidos a palidotomia bilateral simultânea. 5 talamotomias (núcleo VIM) foram acrescentadas no mesmo tempo para pacientes com tremor. Os resultados sugerem que PPV é um procedimento seguro e altamente eficaz para os sintomas da doença de Parkinson.

PALAVRAS-CHAVE: doença de Parkinson, palidotomia póstero-ventral, talamotomia VIM, palidotomia póstero-ventral simultânea, estereotaxia.

The understanding of pathophysiology of Parkinson's disease (PD), the signs and symptoms and also the improvement of modern techniques in neuroradiology, functional neurosurgery and neurophysiology assessment have renewed the right place of surgery in PD. Leksell's posteroventral pallidotomy $(\mathrm{PVP})^{1,2}$ has become the procedure of choice. The indications are: rigidity, akinesia or bradykinesia, muscle pain, L-Dopa induced dyskinesias and resting tremor. Ventrolateral thalamotomy is more indicated for those PD patients with resting and intention tremor, and those who initially did not respond to pallidotomy for tremor. It is not uncommon a combination peroperatively of pallidotomy and ventralis intermedius (VIM) thalamotomy if the tremor does not respond satisfactorily after $\mathrm{PVP}^{1,3-5}$. This paper report the authors preliminary results on PVP in PD.

*MD, Mestrando em Neurologia pela Universidade Federal de São Paulo (UNIFESP) - Escola Paulista de Medicina (EPM) (São Paulo), Estereolife Neurocirurgia Funcional e Estereotáxica (Rio de Janeiro); **Estereolife - Neurocirurgia Funcional e Estereotáxica; ***Físico-Médico, Estereolife - Neurocirurgia Estereotáxica e Funcional, Hospital Nove de Julho (São Paulo), UNIFESP-EPM. Aceite: 10-junho-1998.

Dr. José Augusto Nasser - Rua do Russel 450/802 - 22010-010 Rio de Janeiro RJ - Brasil. 


\section{METHODS}

\section{Clinical material}

Between January 1996 and April 1997, 20 patients were considered good candidates for pallidotomy. It was performed a protocol before and after surgery with appropriate scales of motor function by the authors.

Nineteen patients presented idiopathic PD and one was postoencephalitic. They suffered from various parkinsonian symptoms such as: resting tremor, intention tremor, rigidity, bradykinesia, dyskinesias, severe fluctuation on-off. All signs and symptoms could be unilateral or bilateral with or without one side predominant. Every patient was submitted to several kinds of drug combination: L-Dopa, bromocriptine, anticholinergic, seleginin, MAO-B inhibitor and amantadine. In spite of these combinations the patients did not respond as well as expected, or the side effects of these drugs had increased their problems.

Pure bradykinesia, with or without minor tremor was the most common symptom. 12 men and 8 women ranged in age from 24 to 74 (mean 61.65). The duration of the illness varied from 3 to 20 years (mean 10.9). 8 patients $(40 \%)$ had unilateral disease and among them 6 had resting tremor as predominant symptom. PVP was the first procedure with or without resting or intention tremor. If the tremor does not change peroperatively, a VIM thalamotomy is added simultaneously. 12 patients $(60 \%)$ had a bilateral disease, being 7 with one side predominant in terms of limitations and candidates to unilateral pallidotomy firstly and if necessary 6 months later performing the other side. 5 clinically advanced parkinsonian patients, almost akinetic, highly rigid with severe L-Dopa induced dyskinesias, non demented, were considered for bilateral simultaneous or staged PVP.

\section{Pre- and postoperative assessment}

The protocol of evaluation is composed by: Unified Parkinson Disease Rate Scale (UPDRS) ${ }^{6}$, Hoehn and Yahr Staging Scale, Schwab and England Functional Scale. Every patient has a videotape. Preoperative baseline evaluations were performed in "off" their medications by one of the authors (Table 1). Postoperatively, patients were scored in the same way as preoperatively, at one week, one month and every three months by the authors. Statistical analysis was performed using: a) frequency distribution; b) non-parametric test statistics (Chi-square) to compare the analysis between pre and post-operative motor function adopting probability level of $5 \%(\mathrm{p}<0.05)$.

Patients with mental deterioration and primary balance disturbance were excluded for surgery.

Table 1. Baseline patient characteristics $(n=20)$.

\begin{tabular}{|c|c|c|c|c|c|c|}
\hline Patient & Age & Sex & $\begin{array}{c}\text { Duration } \\
\text { (yrs.) }\end{array}$ & $\begin{array}{l}\text { UPDRS } \\
\text { motor (off) }\end{array}$ & $\begin{array}{l}\text { Hoehn \& } \\
\text { Yahr (off) }\end{array}$ & PVP side \\
\hline 1 & 59 & $\mathrm{~F}$ & 12 & 44 & 5 & Bilat \\
\hline 2 & 67 & M & 20 & 47 & 5 & Bilat \\
\hline 3 & 59 & M & 17 & 46 & 5 & Bilat \\
\hline 4 & 70 & M & 20 & 49 & 4 & Bilat \\
\hline 5 & 24 & $\mathrm{~F}$ & 10 & 48 & 5 & Bilat \\
\hline 6 & 73 & $\mathrm{~F}$ & 5 & 17 & 3 & $\mathrm{R}^{*}$ \\
\hline 7 & 69 & $\mathrm{~F}$ & 20 & 33 & 4 & $\mathrm{E}$ \\
\hline 8 & 59 & M & 15 & 24 & 2 & $E^{*}$ \\
\hline 9 & 49 & M & 5 & 13 & 1 & $\mathrm{R}$ \\
\hline 10 & 68 & $\mathrm{~F}$ & 4 & 40 & 4 & E \\
\hline 11 & 64 & M & 10 & 17 & 1,5 & E \\
\hline 12 & 63 & M & 3 & 28 & 2 & $\mathrm{R}$ \\
\hline 13 & 65 & M & 12 & 48 & 2,5 & $E^{*}$ \\
\hline 14 & 69 & $\mathrm{~F}$ & 12 & 41 & 3 & $\mathrm{R}$ \\
\hline 15 & 57 & $\mathrm{~F}$ & 4 & 19 & 1 & $\mathrm{D}^{*}$ \\
\hline 16 & 58 & $\mathrm{~F}$ & 5 & 17 & 1 & $\mathrm{D}^{*}$ \\
\hline 17 & 57 & M & 10 & 32 & 2 & $\mathrm{E}$ \\
\hline 18 & 59 & M & 10 & 13 & 1,5 & E \\
\hline 19 & 51 & M & 10 & 33 & 2,5 & E \\
\hline 20 & 74 & M & 15 & 40 & 4 & $\mathrm{E}$ \\
\hline
\end{tabular}

* PVP plus VIM thalamotomy. 


\section{Surgical technique}

The stereotactic arc is fixed under local anesthesia (lidocaine $2 \%$ ), then the patient is transferred to the radiology service to get a computerized tomography, now called estereotomography, with nine fiducials on our system ("N" shaped fiducials). After everything is aligned, the scanner is started and slices of 2 mm are processed and the images are acquired. Every image is transferred to the Workstation and the planning software is started (MSPS - A Alaminos Bouza - São Paulo) for edition and fusion with the Schaltembrand-Wahren Atlas. The Leksell's target slight modified by Laitinen ${ }^{1}$ to the globus pallidum internum (GPI) is defined by: $2-3$ mm anterior to the midcomissural point (MCP), $6 \mathrm{~mm}$ below the AC-PC line and 18-22 $\mathrm{mm}$ lateral to the middle of III ventricule $^{7-9}$. The cylindrical lesion resulted is around $100-150 \mathrm{~mm}^{3}$. It is used a thermistor electrode $(1.8 \mathrm{~mm}$ diameter, $30 \mathrm{~cm}$ long and $4 \mathrm{~mm}$ exposure tip). Under local anesthesia, again with lidocaine $2 \%$, it is performed the approach guided by stereotactic references using the Stereotactic System ETM-03B (Micromar - Diadema - SP).

The electrode is positioned right into the pallidum (GPI) and it is connected with the radiofrequency generator (RFG - Radionics - Burlington, MA - USA). The next step is to check the position by measuring the impedance values which is about $400 \mathrm{Ohms}$. Then the stimulation is started with $6 \mathrm{~Hz}, 1-8 \mathrm{~V}, 60 \mathrm{~Hz}, 1-8 \mathrm{~V}$ and $100 \mathrm{~Hz}, 1-5 \mathrm{~V}$. This stimulation try to map where the optic tract is, because in this protocol the authors initiate the position of the electrode tip at the lowest level just above the optic tract and then start to move up in sequence. If any visual sign is registered or the impedance drops precipitously the electrode position is modified. After the stimulation is completed the first lesion is made with $150 \mathrm{~mA}$ and $75^{\circ} \mathrm{C}$ in 60 seconds. While the lesion is being made, the patient is asked to move the contralateral side and to count and answer questions, so that the surgeon can detect the development of any weakness and check the abnormal movements. The initial effects are analyzed and the two more lesions are accomplished $2 \mathrm{~mm}$ and $4 \mathrm{~mm}$ above. Sometimes when it is performing a pallidotomy and the tremor does not respond to this target, the authors complement with a thalamotomy (VIM) simultaneously. The VIM nucleus is situated $5 \mathrm{~mm}$ anterior to posterior comissure at AC-PC line, $1 \mathrm{~mm}$ above of intercomissural plane and 11.5 lateral to the III ventricule wall. On both targets (GPI and VIM) individual anatomical variations are corrected by fusion between stereotactic Atlases and patient's images (CT and/or MRI). The volume lesion is $40-60 \mathrm{~mm}^{3}$.

\section{RESULTS}

Ten unilateral PVPs (50\%) were performed for 6 patients with unilateral disease and 4 patients with bilateral symptoms but one side predominant. 5 PVPs plus VIM thalamotomies (25\%), three

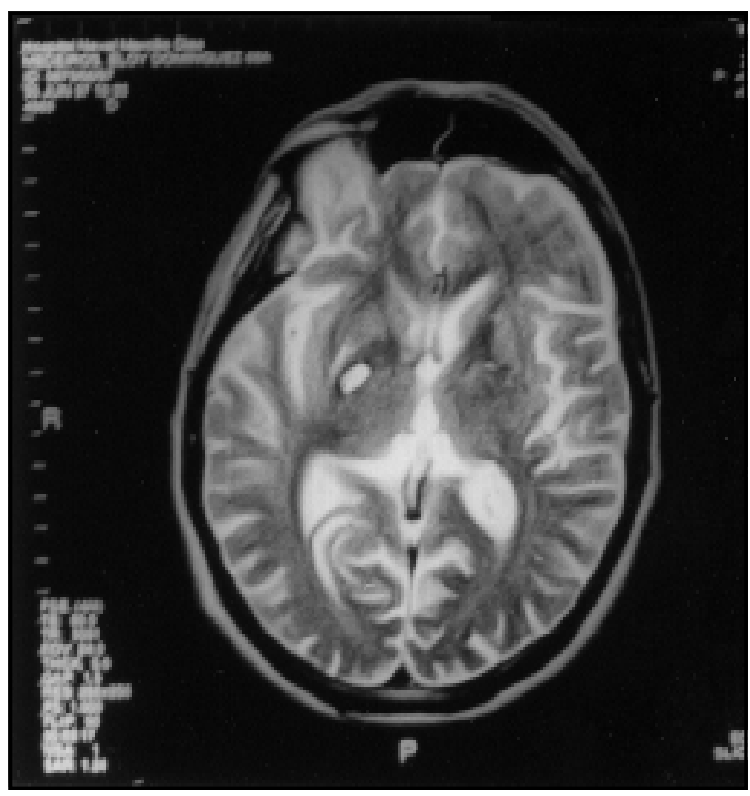

Fig 1. MRI in T2 sequence 6 months after unilateral PVP showing the size and the anatomic position of the lesion in GPI. 


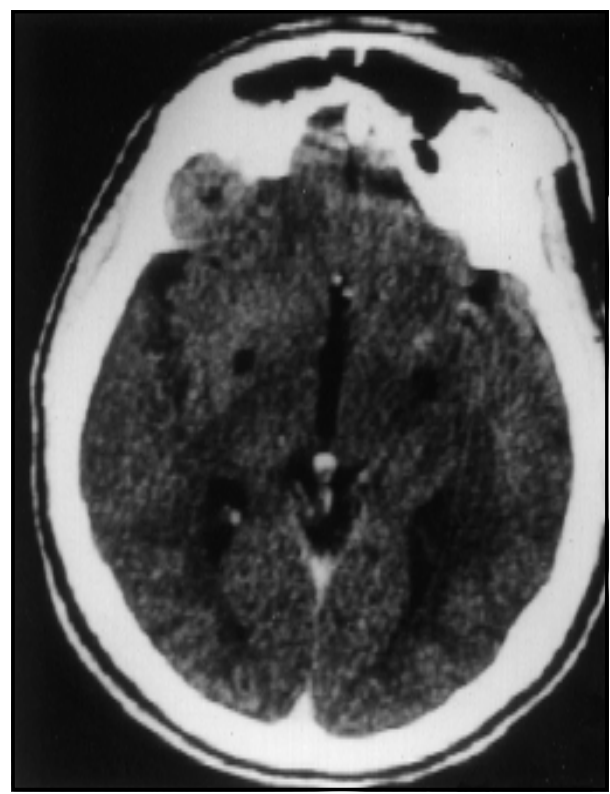

Fig 2. CT scan without contrast 6 months after bilateral simultaneous PVP showing the two lesions in the GPI.

had resting and intention tremor and 2 had only resting tremor in one side, they did not show any change during PVP. Finally 5 patients in Hoehn and Yahr stage scale 5 underwent a bilateral simultaneously PVP (25\%) (Figs 1 and 2).

Most results could be noted right after surgery or in the following days. It was observed total reduction of the tremor in all these patients. In two cases of PVPs the tremor became slow and 20 days after surgery disappeared. The mean of Hoehn and Yahr scores in "off" reduced from 2.75 to $1.5(\mathrm{p} \leq 0.01)$. The mean of Schwab and England scores increased from 59.50 to $75(\mathrm{p} \leq 0.045)$. The total mean UPDRS score was significantly reduced from 32.35 to 6.9 postoperatively $(\mathrm{p} \leq 0.01$ ). Individually UPDRS scores before and after surgery are in Table 2 . These preliminary results show a remarkable improvement after PVP $(\mathrm{p} \leq 0.05)$ in all functional assessments, except for facial expression, speech and posture.

About the advanced PD patients who underwent bilateral simultaneously PVP, 4 had excellent results and one good result. The mean UPDRS score in these 5 patients reduced from 43.6 to 12.4 $(\mathrm{p} \leq 0.01)$. Hoehn Yahr staging scale reduced from 4.8 to 3.6 ( $\mathrm{p} \leq 0.07)$. The patients did not have speech problems so far, neither permanent mental deterioration. All them became drowsy postoperatively but gradually they recovered in 2 to 4 days. Transient mental confusion was seen in 2 patients (40\%). The most expressive findings were the reversal of akinetic symptoms and elimination of dyskinesia and severe "off" periods.

There were some transient and permanent complications. Transient speech problems (10\%) specially after PVP combined with VIM thalamotomy. $20 \%$ presented transitory facial asymmetry. Foot apraxia was observed in $10 \%$. Somnolence is frequent in older patients ( $>65$ years); it occurred in $35 \%$. Mental confusion was observed in $40 \%$, specially in advanced PD patients. Permanent deficit was a hemianopic defect in the lower quadrant contralateral to the PVP (5\%). 
Table 2. Pre and postoperative UPDRS scores terms of distribution of frequency for 20 DP patients underwent PVP between January until April 1997. Statistical non-parametric test (Chi-square). 3. months preliminary results in PD surgery.

\begin{tabular}{|c|c|c|c|c|c|c|c|c|c|c|c|c|c|c|c|c|c|}
\hline \multirow[t]{2}{*}{ Symptoms } & \multicolumn{2}{|c|}{ Speech } & \multicolumn{2}{|c|}{$\begin{array}{c}\text { Facial } \\
\text { expression }\end{array}$} & \multicolumn{2}{|c|}{ Dyskinesia } & \multicolumn{2}{|c|}{$\begin{array}{l}\text { Arm } \\
\text { resting } \\
\text { tremor }\end{array}$} & \multicolumn{2}{|c|}{$\begin{array}{l}\text { Leg } \\
\text { resting } \\
\text { tremor }\end{array}$} & \multicolumn{3}{|c|}{$\begin{array}{c}\text { Action of } \\
\text { posture } \\
\text { tremor }\end{array}$} & \multicolumn{2}{|c|}{ Rigidity } & \multicolumn{2}{|c|}{ Finger taps } \\
\hline & \multicolumn{2}{|c|}{ Pre Post } & \multicolumn{2}{|c|}{ Pre Post } & \multicolumn{2}{|c|}{ Pre Post } & \multicolumn{2}{|c|}{ Pre Post } & \multicolumn{2}{|c|}{ Pre Post } & \multicolumn{3}{|c|}{ Pre Post } & \multicolumn{2}{|c|}{ Pre Post } & \multicolumn{2}{|c|}{ Pre Post } \\
\hline 0 & 4 & 11 & 4 & 5 & 11 & 18 & 5 & 18 & 9 & 19 & 9 & 19 & & & 15 & & 11 \\
\hline 1 & 9 & 7 & 6 & 6 & 3 & 2 & 7 & 2 & 4 & 1 & 2 & 2 & & & 5 & & 7 \\
\hline 2 & 6 & 2 & 5 & 4 & 4 & & 2 & & 2 & & 6 & 1 & & 1 & & 2 & 2 \\
\hline 3 & 1 & & 5 & 5 & 2 & & 1 & & 1 & & 2 & 2 & & 2 & & 2 & \\
\hline 4 & & & & & & & 5 & & 4 & & & 1 & & 17 & & 16 & \\
\hline$\chi^{2}$ & 6.5 & 52 & 0.2 & 22 & & .89 & & 3.13 & & .37 & & 12.14 & & 40.00 & & 36. & .00 \\
\hline$P$ value & 0.0 & 08 & 0.9 & 97 & & .04 & & .01 & & .01 & & 0.01 & & 0.01 & & 0.0 & 01 \\
\hline \multirow[t]{2}{*}{ Symptoms } & \multicolumn{2}{|c|}{$\begin{array}{c}\text { Hand } \\
\text { movements }\end{array}$} & \multicolumn{2}{|c|}{$\begin{array}{c}\text { Rapid } \\
\text { alternating } \\
\text { movements }\end{array}$} & \multicolumn{2}{|c|}{$\begin{array}{l}\text { Leg } \\
\text { agility }\end{array}$} & \multicolumn{2}{|c|}{$\begin{array}{c}\text { Arising } \\
\text { from a } \\
\text { chair }\end{array}$} & \multicolumn{3}{|c|}{$\begin{array}{l}\text { Posture } \\
\text { resting }\end{array}$} & \multicolumn{2}{|c|}{ Gait } & \multicolumn{2}{|c|}{$\begin{array}{l}\text { Posture } \\
\text { stability }\end{array}$} & \multicolumn{2}{|c|}{$\begin{array}{l}\text { Body } \\
\text { brady- } \\
\text { kinesia }\end{array}$} \\
\hline & Pre $\mathrm{F}$ & Post & Pre & Post & & re Post & & re Pos & & Pre 1 & Post & Pre & Post & Pre & Post & Pre & Post \\
\hline 0 & & & & 10 & & 16 & & 9 & & & 4 & & 12 & 1 & 12 & & 11 \\
\hline 1 & & 15 & & 9 & & 4 & & 11 & & 4 & 5 & 12 & 5 & 3 & 4 & 5 & 5 \\
\hline 2 & 3 & 5 & 4 & 1 & 3 & & & 1 & & 8 & 3 & & 1 & 6 & 2 & 5 & 4 \\
\hline 3 & 6 & & 4 & & 6 & & & 1 & & 8 & 8 & 7 & 2 & 3 & 2 & 3 & \\
\hline 4 & 11 & & 12 & & 11 & & & 13 & & & & 1 & & 7 & & 7 & \\
\hline$\chi^{2}$ & 40.0 & 00 & & 6.80 & & 0.00 & & 26.25 & & 6.38 & & 19. & & 18. & 65 & & 1.11 \\
\hline$P$ value & 0.0 & 01 & & 0.01 & & 0.01 & & 0.01 & & 0.0 & & 0.0 & 01 & 0.0 & 01 & & .01 \\
\hline
\end{tabular}

\section{DISCUSSION}

Surgical treatment as help for people with movement disorders was first noted by Sir Victor Horsley. He advised precentral cortex resection to treat athetosis. Meyers was the first surgeon to indicate extrapyramidal surgery to treat $\mathrm{DP}^{7}$. He got excellent results operating on initially caudate nucleus and later on included anterior limb of internal capsule and pallidothalamic fibers at the level of the ansa leticularis. With his good results in tremor and rigidity he stimulated Fénelon, Browder, Guiot and Brion ${ }^{11,12}$. In 1950 Spiegel, Wycis and Talairach published their results with stereotactic treatment of movement disorders doing pallidotomies and ansotomies. The pallidal target that time was in the anterodorsal and medial part of the nucleus; however, this target was not so good to tremor. In 1952, Lars Leksell checking this target, concluded that it had to be changed. Then he moved the pallidum target to the posteroventral and lateral pallidum. The PVP were created and good results were confirmed by Svennilson et al. ${ }^{9}$ and recently by Laitinen and Hariz ${ }^{2}$. However in 1954 Hassler and Riechert had begun the surgery in the ventrolateral nucleus of the thalamus to DP and this procedure became the most popular in the whole world to treat DP symptoms. In this decade after Laitinen published his and Leksell's results with PVP, this procedure was reinvented 
and most centers of the world adhered to this technique ${ }^{1-3,10,11}$. Recently, several laboratory experiments with MPTP animal models have suggested that the parkinsonian symptoms, including tremor, are related in the pallidum ${ }^{1,12-16}$. It is important to note the study of Eidelberg with PET scan in PD patients showing an increased glucose metabolism in the pallidum. And in preoperative and postoperative activity in PD underwent a PVP showed a pallidothalamic desinhibition and the increasing of activity in the supplementary motor area ${ }^{14,17-20}$.

Today there is a strong evidence that not only akinesia or bradykinesia, rigidity and hypertonia, drug-induced dyskinesias but the tremor, specially resting tremor, improve significantly with PVP. Studies have been done in many centers with peroperative monitoring with microrecording. Taha et al. ${ }^{21}$ recently showed in an elegant paper analyzing 298 neurons in 38 patients the somatotopic organization of kinesthetic cells in globus pallidus of patients with PD. Arm cells were clustered at the rostral and caudal segments of GPI and leg cells were clustered centrally. And also tremorsynchronous cells were found in GPI, similar to the findings of Filion and Tremblay, who suggested that increased inhibitory output of GPI in PD probably hyperpolarizes thalamic neurons and induces bursting activity during the waking state ${ }^{18,21-24}$.

The results showed that every patient did well after PVP regarding gait problems, bradykinesia, side effects of drugs, freezing, rigidity and tremor. Most unilateral PD patients had a reduction of their medications days after surgery, however only $30 \%$ with advanced PD in this series could have some drug reduction.

PVP is one of the good instruments to help PD patients. The results of the present series confirm the good results of the other series ${ }^{1-4}$. The UPDRS analysis of these 20 patients showed in three months remarkable improvement except for facial expression, speech and postural. It differs slightly from Iacono's series ${ }^{4}$, but it is in agreement with Shuurman series ${ }^{11}$. The authors have found good effect in gait dysfunction in contrast with Gross reports ${ }^{24}$.

The authors are satisfied with simultaneous bilateral PVP in advanced PD ${ }^{25,26}$. These results have shown substantial improvement. The most important point is the right selection of those patients. The patient is prepared to bilateral PVP if it is feasible. And also intensive rehabilitation should start soon after surgery. It has to be realized that any improvement of those patients and decreasing the side effects of the drug can help them in quality of live.

This series differs in term of incidence of side effects and complications of Hariz series, which shows infection, subcortical haematoma and paresis of legs. Other complications are at the same range as presented by the authors.

These preliminary results of 20 DP patients including PVP alone, PVP combined with thalamotomy (VIM) and simultaneous bilateral PVP confirm the good results of the literature $1,2,4,24$.

The modern PVP is part of modern neurosurgery. Deep chronic pallidal stimulation was reported by Siegfried and Wellis ${ }^{27}$ or thalamic/subthalamic stimulation by Beric et al. ${ }^{28}$. It remains to be proven whether stimulation is better than ablation ${ }^{29}$. The results will need long time to be considered. Stimulation is also modern technique with the advantage of being reversible and even thalamic can be performed bilaterally. However the future is going to be the neural transplant with better results ${ }^{30}$. It remains to define those transplant variables that optimize the likelihood that implanted cells will survive and provide clinical benefit and to determine if subpopulations of PD patients are more likely to respond to this procedure.

\section{REFERENCES}

1. Laitinen LV. Pallidotomy for Parkinson's disease. Neurosurg Clin N Am 1995;6:105-112.

2. Laitinen LV, Hariz MI. Movement disorders. In Youmans JR (ed): Neurological surgery. 4.Ed. Philadelphia: W.B. Saunders, 1996;6:3575-3609.

3. Iacono RP, Shima F, Lonser RR. The results, indications, and physiology of posteroventral pallidotomy for patients with Parkinson's disease. Neurosurgery 1995;36:1118-1127. 
4. Iacono RP, Lonser RR, Ulloth JE, Shima F. Postero-ventral pallidotomy in Parkinson's disease. J Clin Neuroscience 1995;2:140-145.

5. Hariz MI, De Salles AAF. The side-effects and complications of posteroventral pallidotomy. Acta Neurochir 1997;Suppl $68: 42-48$

6. Richards M, Marder K, Cote L, Mayeux R . Interrater reliability of the unified Parkinson's disease rating scale motor examination. Mov Disord 1994;9:89-91.

7. Laitinen LV. Brain targets in surgery for Parkinson's disease: results of a survey of neurosurgeons. J Neurosurg 1985;62:349-351.

8. Laitinen LV, Bergenheim AT, Hariz MI. Leksell's posteroventral pallidotomy in the treatment of Parkinson's disease. J Neurosurg 1992;76:53-61.

9. Svennilson E, Torvik A, Lowe R. Treatment of parkinsonism by stereotactic thermolesions in the pallidal region: a clinical evaluation of 81 cases. Acta Psychiatr Scand 1960;35:358-377.

10. Anno Y, Hirao J, Okamoto $\mathrm{H}$ et al. Juvenile parkinsonism treated with bilateral pallidotomies. Neurol Med Chir (Tokyo) 1995;35:680-682.

11. Shuurman PR, De Bie RMA, Speelman JD, Bosch DA. Posteroventral pallidotomy in movement disorders. Acta Neurochir 1997;Suppl 68:14-17.

12. Bergman H, Wichmann T, DeLong MR. Reversal of experimental parkinsonism by lesions of the subthalamic nucleus. Science 1990;249:1436-1438.

13. Albin RL, Young AB, Penney JB . The functional anatomy of basal ganglia disorders. TINS 1989;12:366-375.

14. Bakay RAE, DeLong MR, Vitek JL. Posteroventral pallidotomy for Parkinson's disease. (Letter). J Neurosurg 1992;77:487-488.

15. Vitek JL, Baron M, Kaneoke Y. Microelectrode-guided pallidotomy is an effective treatment for medically intractable Parkinson's disease (Abstract). Neurology 1994;44(Suppl 2):A304.

16. Meyer CHA. Unilateral pallidotomy for Parkinson's disease promptly improves a wide range of voluntary activities especially gait and trunk movements. Acta Neurochir 1997;Suppl 68:37-41.

17. Baron M, Turner RS, Vitek JL. Lesions of the internal segment of the globus pallidus (Gpi) in parkinsonian patients improve motor performance bilaterally (Abstract). Neurology 1994; 44(Suppl 2):A304.

18. Berié A, Sterio D, Dogali M. Characteristics of pallidal neuronal discharges in Parkinson's disease patients. Adv Neurol 1996;69:123-128.

19. Grafton ST, Waters C, Sutton J. Pallidotomy increases activity of motor association cortex in Parkinson's disease: a positron emission tomographic study. Ann Neurol 1995;37:776-783.

20. Hirato M, Ishihara J, Horikoshi S, Shibazaki T, Ohye C . Parkinsonian rigidity, dopa-induced dyskinesia and choreadynamic studies on the basal ganglia-thalamocortical motor circuit using PET scan and depth microrecording. Acta Neurochir (Wien) 1995;Suppl 64:5-8.

21. Taha JM, Favre J, Baumann TK, Burchiel K . Characteristics and somatotopic organization of kinesthestic cells in the globus pallidus of patients with Parkinson's disease. J Neurosurg 1996;85:1005-1012.

22. Kopyov O, Jacques D, Duma C, et al. Microelectrode-guided postereoventral medial radiofrequency pallidotomy for Parkinson's disease. J Neurosurg 1997;87:52-59.

23. Lozano AM, Hutchison W, Kiss Z. Methods for microelectrode-guided posteroventral pallidotomy. J Neurosurg 1996;84:194-202.

24. Gross RE, Lozano AM, Lang AE, Tasker RR, Hutchison WD, Dostrovsky JO. The effects of pallidotomy on Parkinson's disease: study design and assessment techniques. Acta Neurochir 1997;Suppl 68:24-28.

25. Couldwell WT, Grafton ST. Pallidotomy in advanced Parkinson's disease (Letter). Neurosurgery 1995;37:1234.

26. Siegfried J, Lippitz B. Bilateral chronic electrostimulation of the ventroposterolateral pallidum: a new therapeutic approach for alleviating all parkinsonian symptoms. Neurosurgery 1994;35:1126-1130.

27. Siegfried J, Wellis G. Chronic electrostimulation of ventroposterolateral pallidum: follow-up. Acta Neurochir 1997;Suppl 68:11-13.

28. Beric A, Sterio D, Dogali M, Alterman R, Kelly P. Electrical stimulation of the globus pallidus preceding stereotactic posteroventral pallidotomy. Stereotactic Funct Neurosurg 1996;66:161-169.

29. Haris MI. Controversies in pallidal surgery. Acta Neurochir 1997;Suppl 68:1-10.

30. Olanow CW, Freeman TB, Kordower JH. Neural transplantation as a therapy for Parkinson's disease. Adv Neurol 1997;74:249-269. 